\title{
Characteristics Of the Fragmentation of Students' Thinking Structures with Cognitive Style Field Dependent on The Material Exponential Equation
}

\author{
Rachmat Imam Muslim $\left.{ }^{1} \bowtie\right)$, Budi Usodo ${ }^{2}$, Hasih Pratiwi ${ }^{2}$ \\ ${ }^{1}$ Sekolah Tinggi Keguruan dan Ilmu Pendidikan Muhammadiyah Batang \\ ${ }^{2}$ Postgraduate FKIP Mathematics education, Universitas Sebelas Maret, Surakarta \\ Corresponding author. Email: ri.muslimembstkip.ac.id
}

Accepted: May 20,2021

Approved: June 12, 2021

Published: July 25, 2021

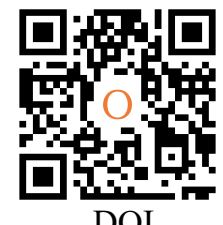

DOI

Publisher: El Syits Project
Abstract - Fragmentation of thinking structure is a condition where information storage does not work well. Related to processing information, one of the factors that affect an individual's ability to store information is cognitive style. Field Dependent (FD) cognitive style requires more guidance from others in order to understand the material well. With the characteristics possessed by students with FD cognitive style, it is very possible for students with FD cognitive style to experience fragmentation of thinking structures. Therefore, the researchers tried to explore the characteristics of the form of fragmentation that might occur in students with FD cognitive style on the exponential equation material. This study uses a qualitative descriptive method that describes the characteristics of the fragmentation of the thinking structure of students with FD cognitive style. From the results of the study, it was found that students with the FD cognitive style experienced all types of fragmentation of thinking structures. This is reflected in the difficulty of students in solving problems that have not been exemplified by the teacher. Even though the subject knows the concept, when faced with different problems, they have difficulty solving them.

Keywords - Cognitive Style, Field Dependent, Thinking Structures.

\section{INTRODUCTION}

In essence, mathematics was born from the fruit of human thought to facilitate problems that arise from human activities. The role of mathematics is considered very large for life. Many mathematical theories have been found to facilitate problem solving in life, both from simple problems to complex problems (1). Because of the importance of mathematics, it is necessary to teach it from basic education to higher education. Mathematics also plays a role in training students to think critically. Mathematics in education can also serve to develop students' thinking skills (2). In addition, many aspects can be developed through learning mathematics such as teaching students how to think analytically, reason, solve problems and how to prove the truth of existing arguments (3).

Learning mathematics is not just learning to memorize formulas. Studying mathematics prioritizes understanding concepts rather than memorizing. Abstract mathematical concepts must be formed correctly. Teaching mathematics by linking problems that are often encountered on a daily basis will make mathematics learning meaningful rather than teaching mathematics only by memorizing formulas (4). The correct concept will be formed in the structure of students' thinking when learning leads students to find their own concepts based on the activities they are doing (5). Through concrete examples, students feel the benefits of learning mathematics. Mathematics teaches concepts as rules that can be used to facilitate problem solving. Understanding of mathematical concepts is the basis for meaningful mathematics learning (6). Students are said to understand a concept if they are able to identify or explain information verbally and are able to look for relationships between concepts (7).

In fact, mathematics is still often considered scary for students. The abstract nature of mathematical material makes it difficult for some students to learn mathematics (8). Often students' difficulties in learning mathematics are seen when students work on problems or solve problems. Lack of understanding of concepts makes it difficult for students to solve problems or when teachers change the form of questions (9). In problem solving, the lack of linkage between new mathematical concepts and previously studied concepts is one of the causes of students' difficulties in learning mathematics (10). 
When faced with a problem, students will try to think back to the resources they have to find solutions through the thinking process. Of course, it will not be a problem when the resources that students have are complete. Students easily find solutions either by identifying to model first or directly looking for solutions. Different things will certainly be experienced by students who do not have sufficient resources. Resources related to the thinking process, namely the structure of thinking. The thinking structure consists of schemata that are interconnected and form a schema (11). Therefore, the structure of thinking is closely related to the construction of concepts. If the concept is understood correctly, the student's thinking structure will be correct, but if the construction still does not understand correctly, the subject's thinking structure will have problems. With a problem with the structure of students' thinking, it will result in the fragmentation of the thinking structure. Fragmentation of thinking structures is defined as disruption of thinking processes due to wrong procedures or inefficient storage in the brain.

Fragmentation in the structure of thinking according to (11) can take the form of: 1) Construction holes that occur when students are unable to connect existing concepts so that the concept construction is incomplete, 2) pseudo Construction occurs when students do not understand the concept correctly. Pseudo can be in the form of pseudo analytic - pseudo conceptual or pseudo correct - pseudo false $(11,12), 3)$ random structures occur when students in constructing concepts do not pay attention to the necessary conditions and 4) structure Separation occurs when students actually understand the concepts needed but students cannot connect these concepts to solve problems. This can happen when learning only focuses on memorization so that students are accustomed to imitating the steps exemplified by the teacher.

The material on exponential function equations taught at the high school level can be used to test whether or not there is fragmentation of thinking structures experienced by students. The equations of exponential functions can contain many algebraic concepts that have been taught at the junior high school level. Through the equation of the exponential function, problems or solutions can be arranged that contain several concepts that have been studied by students at the previous level of education. The concept of number operation rules, linear equations, function concepts and set concepts can be explored by making questions that contain these concepts. Several studies have shown that when given exponential equation questions, students often encounter difficulties. According to research results from (13). In studying exponential material, students still experience several obstacles in the form of conceptual, procedural and operational techniques barriers. Procedural errors in solving problems related to the concept of exponential equations in the form of errors in arithmetic operations procedures and variable example (14). The results of the correct answers from students in solving problems related to the concept of exponential equations do not necessarily indicate that these students have understood the concept correctly. Often students can answer correctly but the understanding related to the concept of exponential equations possessed by students is still unclear. Students cannot explain the steps used and only memorize formulas (15).

One of the influencing factors in processing and processing information into knowledge for students is cognitive style. From the psychological aspect, thinking style plays a role in shaping students' knowledge (16). Cognitive style plays a role in influencing how students perform self-management to determine activities consciously and used to organize, receive and process information. Based on their cognitive style, students will have a unique way of how individuals process information in the form of how individuals memorize, understand, think and solve problems $(17,18)$. Cognitive styles are divided into two types, namely Field Dependent (FD) and Field Independent (FI) (19). The two cognitive styles have different ways of processing information into knowledge. FI cognitive style is more likely to be able to think analytically and independently. Meanwhile, students with FD style need the help of others to understand the material (20).

Based on the background described above, the researchers tried to reveal the characteristics of the type of fragmentation of thinking structures experienced by students. In this article, the research focuses on the characteristics of what kind of fragmentation often occurs in students with cognitive style field dependent in studying exponential equations.

\section{RESEARCH METHOD}

This research uses descriptive qualitative method. In descriptive qualitative research, the data obtained are in the form of words and observable behavior. This study aims to describe the characteristics of the type of fragmentation of the thinking structure of students with a field dependent cognitive style. in studying exponential equations. The subjects of this study were 2 students of class X Madrasah Aliyah Muhmmadiyah Limpung who were selected using purposive sampling method. The purposive sampling method was used with the consideration that there was a covid-19 pandemic that had not ended so that the determination of subjects in the study could not be carried out freely as in normal circumstances. The data collection in this study used the think aloud and interview methods. The 
Rachmad Imam Muslim, et al., Characteristics of the fragmentation of students' thinking structures ...

think aloud method is believed to be effective for knowing the thinking process. Then interviews were conducted to ensure that the data obtained using the think aloud method were valid.

To facilitate the think aloud process, the subject is given a mathematical test instrument that has been validated by three validators. The test instruments used are as follows:

\begin{tabular}{|c|c|}
\hline (In Indonesia) & lish) \\
\hline $\begin{array}{l}\text { 1. Tentukan Himpunan penyelesaian yang memenuhi } \\
\text { persamaan }\left(x^{2}-6 x+9\right)^{x-1}=(x-3)^{x+1} !\end{array}$ & $\begin{array}{l}\text { 1. Determine the set of solutions that satisfy the } \\
\text { equation }\left(x^{2}-6 x+9\right)^{x-1}=(x-3)^{x+1} \text { ! }\end{array}$ \\
\hline $\begin{array}{l}\text { 2. Jumlah orang di misalkan } P \text { (dalam jutaan) yang } \\
\text { menggunakan dua aplikasi browser internet yang } \\
\text { berbeda untuk mengakses internet selama } t \\
\text { minggu. Penggunaan aplikasi tersebut dimodelkan } \\
\text { sebagai berikut. } P_{1}(t)=1,5^{t+4} \text { dan } P_{2}(t)= \\
2,25^{t-3,5} \text { untuk masing-masing aplikasi yang } \\
\text { digunakan. Pada minggu ke berapakah pengguna } \\
\text { kedua aplikasi berjumlah sama? }\end{array}$ & $\begin{array}{l}\text { 2. The number of people in let } P \text { (in millions) } \\
\text { use two different internet browser applications } \\
\text { to access the internet during } t \text { weeks. The use } \\
\text { of the application is modeled as follows. } \\
P_{1}(t)=1,5^{t+4} \text { and } P_{2}(t)=2,25^{t-3,5} \text { for } \\
\text { each application used. In what week is the } \\
\text { number of users of both applications the } \\
\text { same? }\end{array}$ \\
\hline
\end{tabular}

Fig. 1. Question test

Of the two questions, the subject answered by expressing what was in his mind to solve the problem (think aloud). The student's expression that appears is a representation of the subject's thinking structure in processing the resources he has in his brain where the resources owned will affect the subject's thinking process in finding solutions to the given problem solving. To ensure the validity of the data, this research uses triangulation method. Method triangulation is done by comparing data obtained from the think aloud method with data obtained from the interview method.

\section{RESULT AND DISCUSSION}

Students' mistakes are often a reflection of mastery of concepts for students. Conceptual knowledge is formed from relationships that contain facts and principles (14). These relationships are interconnected and form a schema. According to (11), schema is a knowledge building consisting of schemata. When the schema is incomplete or not in accordance with the flow of problem solving, it will cause obstacles in the process of recalling information or remembering the required information. Inappropriate schemes can occur because when receiving and processing information is not stored properly. From the research results obtained fragmentation that occurs in field dependent students as follows:

\section{CONSTRUCTION HOLES.}

Based on the results of the written answers, it appears that the subject does not know the concept of quadratic equations. The results of the written work of the subject are shown in Figure 3.1 below:

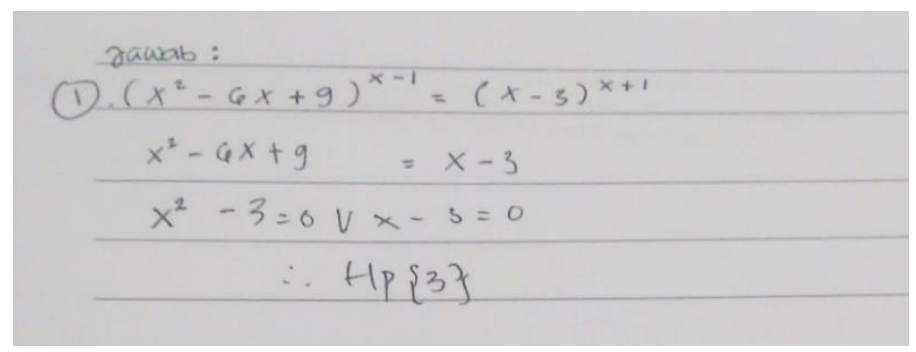

Fig. 2. The results of the answer to question number 1

Based on the answer written by the subject of FD-1, it appears that the subject is unable to simplify the form of $\left(x^{2}-6 x+9\right)$. When unable to simplify the form, the subject's steps in solving problem number one experience an error. The subject does not seem to understand the concept of quadratic equations. understanding the concept that they do not have makes the subject unable to simplify the form of the existing quadratic equation. From the think aloud process, construction holes appear when the subject has difficulty using the concept of quadratic equations to simplify $x^{2}-6 x+9$ which is shown from the subject's think aloud expression when trying to work on problem number 1:

3|V o 1. 1; I s s u e, 1 
Ordinal: Innovation in Research, Development, and Learning on Mathematics Education Journal

FD-1; what is the rank of this, is there something wrong, sir? Is this the rank $x-1$ and $x-1$

FD-1: maybe try the same thing, so just cross out the rank and then equate the base numbers $x^{2}-6 x+9=x-3$

FD-1 : mm... this seems to be simplified to $x^{2}-3=x-3$

From the steps taken by FD-1, the subject did not realize that the $x^{2}-6 x+9$ equation should be can be simplified to $(x-3)^{2}$ so that the right and left sides will have the same basis, but what happens is that the subject of FD-1 thinks there is an error in the question because nothing can be simplified to equalize the basis. The subject then assumes his rank is the same because he suspects that there is a typo in the question.

The same thought process also occurs with the subject of FD-2 when taking the first step to solve problem number 1. The subject of FD-2 reveals that there is nothing that can be simplified to equalize the base or the denominator of the two sides so that they assume there is a writing error in the question. The following is the expression of think aloud subject FD-2:

FD-2 : ok like this... the problem is wrong, sir?

FD-2 : If the problem is like this, it means it's not an exponential equation, sir. As far as I remember, there is no exponential equation with different powers and bases

FD-2 : uh... can this be simplified? Obviously, you can't do it, if you divide the base by how much...

FD-2 : I can't seem to do it either, this is because the difference between the left and right squares doesn't have a square.

From the expression think aloud, the two subjects proved that the subject could not understand the concept of quadratic equations. from the results of the interview, it was also revealed that both subjects considered that the basis could not be simplified. The interview results that prove that the subject is not able to simplify the basis are revealed as the following interview excerpt:

$R \quad$ : if none is the same, can the basis not be simplified so that both sides are equal?

FD-2 : (subject scratching his head trying to think) I can't seem to, sir. If it is divided by any number, the result is that the right and left sides are different, sir, because the one on the right is not the square of the left.

Construction holes occur when the construction of the concept of the subject's quadratic equation has not yet been formed so that when faced with simplifications that require the concept of quadratic equations, the subject is unable to use the concept to change existing equations. The fragmentation that occurs is illustrated in Figure 3.2 below:
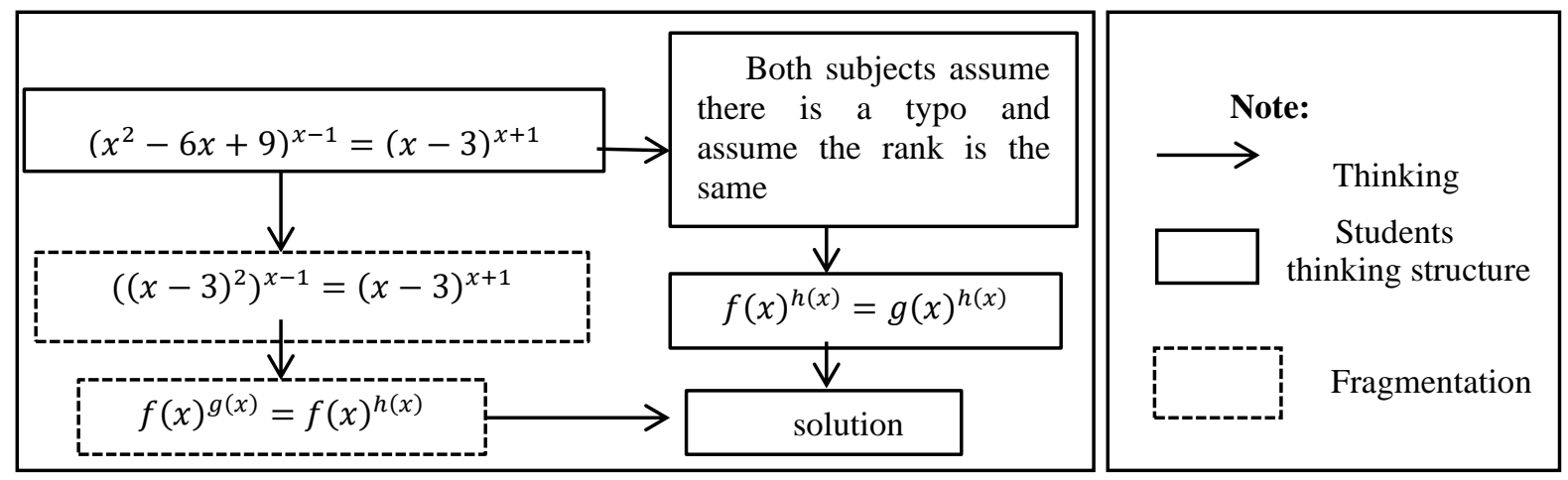

Fig. 3. Fragmentation of construction holes owned by students

\section{PSEUDO CONSTRUCTION}

Pseudo construction occurs when both subjects consider the properties of a quadratic equation if they are the same, then they are crossed out. The subject makes an analogy as in the concept of division as shown in Figure 3.3 from the results of the following subject's answers: 


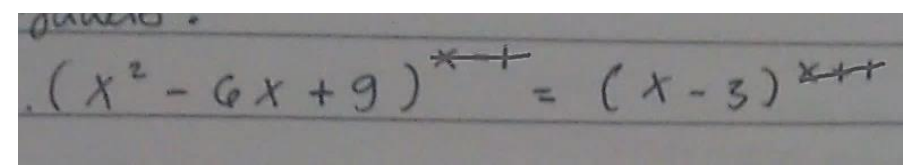

Fig. 4. The results of the subject's work that showed pseudo-thinking.

Students' written answers showed a misunderstanding related to the concept of exponential equation and was confirmed by the subject's expressions during think aloud and interviews. The subject revealed that if there were any that were the same, then they would cross out and count the ones that were not the same. When the exponents are the same then the exponents are crossed out and only calculate the base and vice versa. The subject misunderstood the teacher's instructions when teaching the properties of exponential equations and assumed the teacher gave such an example.

What students do by crossing out the same rank is certainly wrong conceptually, although sometimes it produces the correct answer. The subject does not understand the meaning of why only calculate the base when the exponents are the same. The subject should understand that if the equation is the same, it means that the value will be the same when the basis is also the same, so that what needs to be calculated is that the base is not crossed out to the same rank as analogous to division. Where in the division when there are the same number, it can be crossed out, which means that when it is crossed out it has a value of one. Understanding students who seem right but actually wrong is called pseudo-thinking. The illustration of the pseudo construction experienced by the subject in solving problem number 1 is illustrated in Figure 3.4 below:

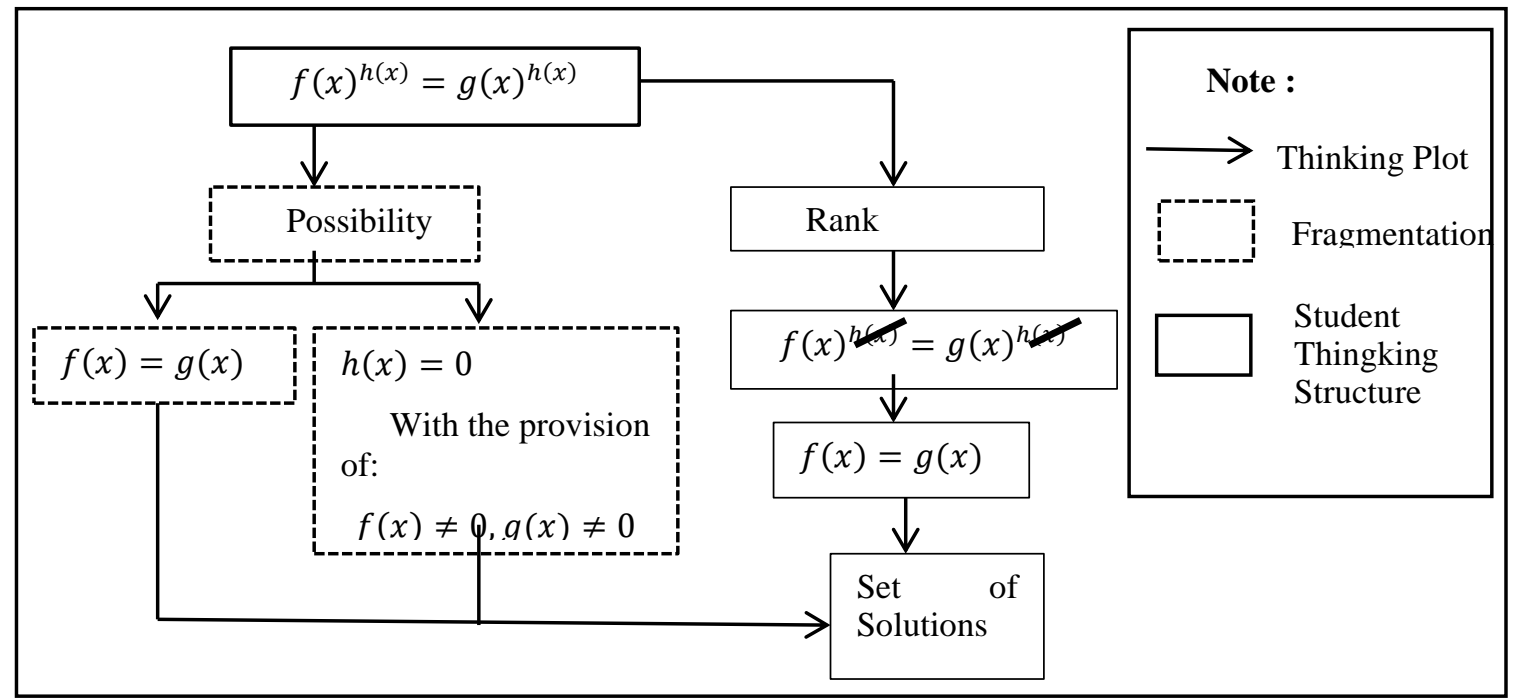

Fig. 5. Fragmentation of pseudo construction types

\section{SEPARATE STRUCTURE}

Fragmentation of the subject's separate structure is seen when working on problem number 2 . The subject of FD1 seems to have used the right steps but then the subject feels unsure and deletes the steps again as in the results of student work shown in Figure 3.3 below:

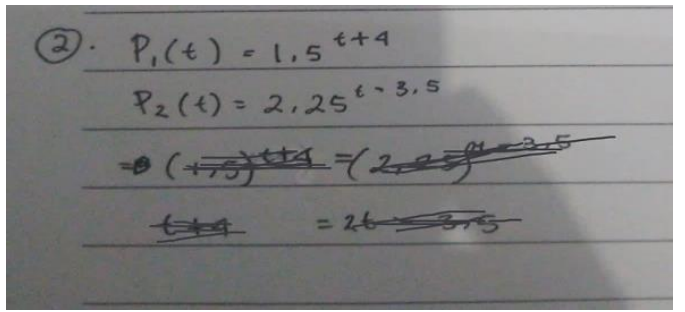

Fig. 6. The results of the work of the subject showing the existence of a separate structure 
The subject deletes the correct steps again. From this step the subject actually already knows the concept that must be used. The subject also understands the properties of the exponential equation when explaining the steps at the time of the interview for question number one. The subject feels unsure that the problem can be solved using the properties of the exponential equation which is expressed by the subject at the time of think aloud such as the quote from the subject's think aloud expression below:

FD-1 : which is known to be $P_{1}(t)=1,5^{t+4}$ and $P_{2}(t)=2,25^{t-3,5}$ mmm how come

FD-1 : (subject crossed out steps that should be correct) er, this is wrong, not an exponential equation like

FD-1 : I don't think we've ever been taught anything like this, sir. If the exponential equation is usually growth, the problem is...

FD-1 : If this is looking for when the application will be the same, sir, this application has not been taught, sir, p1 is 22 and this is how it is done, confused Mr.

Subject assumes that such questions have never been taught. From the results of the interview, the subject revealed that the exponential equation which contains story questions is usually about decay or growth and is different from what was asked about question number two where question number two asks when the number of application users will be the same.

The separate structure of the subject of FD-1 appears when the subject actually knows the concept of the exponential equation as seen from the interview when given the $4^{2 x}=2^{8}$ question, the subject is able to answer with the right steps. However, when faced with story questions such as number two, there was no connection between the concepts possessed by the subject of FD-1 and the questions so that the subject could not continue to take steps to get answers to the problems given. The assumption of the subject of FD-1 that the concepts needed to solve problem number 2 have not been taught by the teacher, proving that the subject is only able to imitate the examples given by the teacher in working on the problem. When the questions given are different, the subject is unable to connect the existing structure into the required problem-solving structure. The fragmentation that occurs in the subject is described as follows:

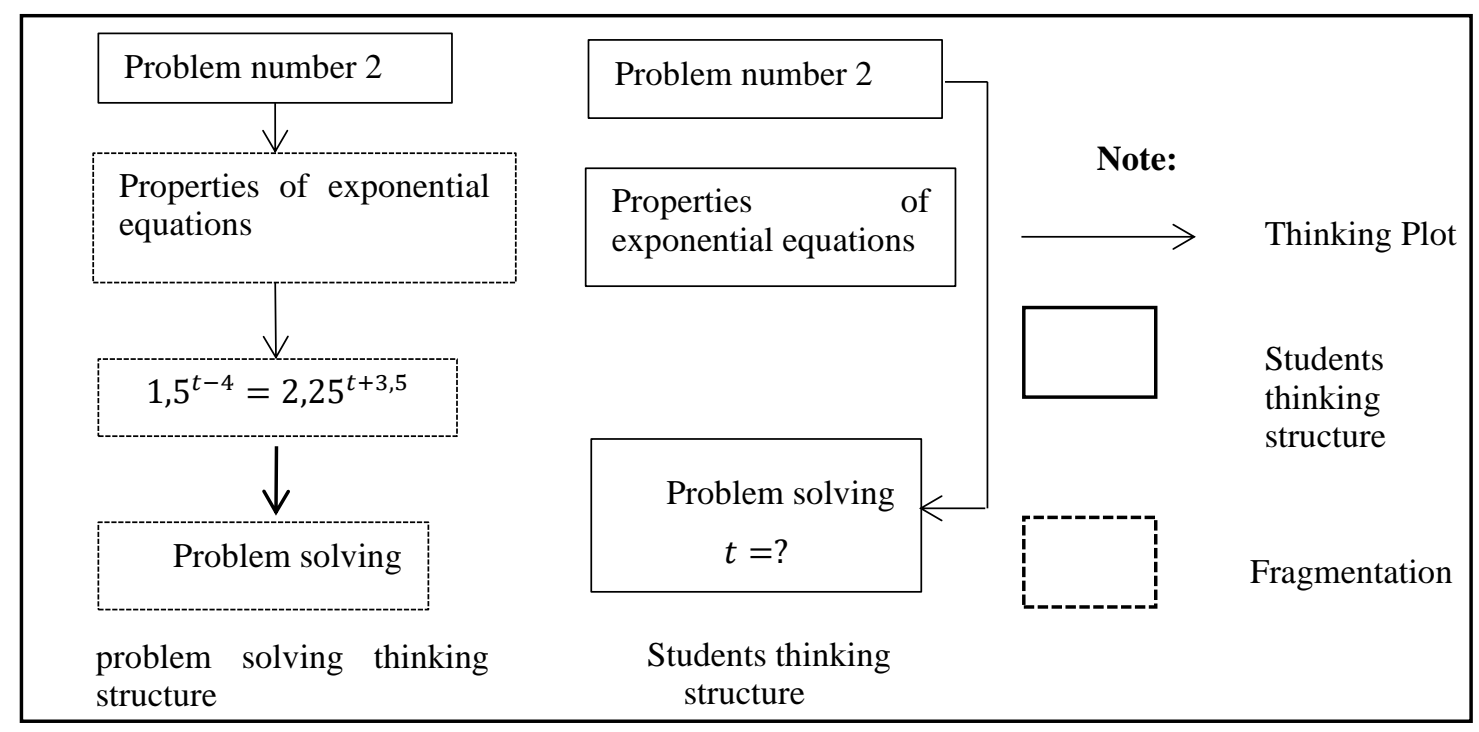

Fig. 7. problem solving thinking structure and Student thinking structure

From the picture above it is shown that the thinking structure of students in solving problem number two has difficulty solving problems because there is no connection between the subject's knowledge of the properties of exponential equations and the problems in the problem. In the absence of this connection, the subject is unable to solve problem number 2 . 


\section{CONCLUSION}

The thinking structure of students certainly cannot be separated from students' understanding of the subject matter that has been obtained previously. Understanding that is less related to previous concepts will lead to fragmentation in the structure of thinking. It has been explained in the introduction that the student's cognitive style will affect how the student processes the information he receives into new knowledge for students. Field dependent cognitive style according to several studies is very dependent on the help of others and lots of examples in order to understand a material. This makes students with a field dependent cognitive style very at risk of experiencing fragmentation of thinking structures. The risk of fragmentation of thinking structures for field dependent students is evident from the results of this study. Of the four fragmentation that may be experienced by students, field dependent students experience all types of fragmentation of thinking structures, especially in the exponential equation material. Fragmentation of students' thinking structures that occur include construction holes, pseudo construction, random structures and separate structures.

Construction holes are seen when the subject does not yet understand the concept of quadratic equations. students assume that equations containing quadratic can only be simplified by dividing. If it cannot be divided, then the quadratic equation cannot be simplified. Pseudo construction occurs when the subject seems to understand the concept of exponential equation correctly but actually the subject's thinking is still wrong. Pseudo construction appears when the subject analogizes the exponential equation with the concept of division where the same number is crossed out. By maintaining such knowledge, the subject can work on the problem correctly, but the real concept is not understood correctly by students. Such thinking will certainly eliminate the meaning of the exponential equation which will annoy students when faced with problems that have never been exemplified by the teacher because the student's understanding is actually a pseudo-understanding. And the last fragmentation experienced by students is a separate structure. Separate structure occurs when the subject cannot connect knowledge related to the properties of exponential equations into problems in the form of story problems. Students assume that the exponential equation is only symbolized by $f(x), g(x)$ and. $h(x)$. Students only imitate the steps of the questions that are often given by the teacher. when faced with unusual questions students are not able to use their knowledge of exponential equations to make steps to solve the problem.

It is very necessary for teachers to know the fragmentation of students' thinking structures in order to find out the causes of errors that are often made by students. By knowing the fragmentation that occurs, the teacher is expected to be able to take anticipatory steps by carrying out the necessary defragmentation to students so that the subject's thinking structure can be reshaped correctly. Without a defragmentation effort from the teacher, the students' thinking structure will be increasingly disorganized. The amount of fragmentation that occurs will certainly make it difficult for students to understand or solve the problems given. When difficulties continue to come to students, what is worse will make students lose their motivation to learn mathematics.

\section{Acknowledgment}

The author would like to thank the principal of MAM Limpung for the permission given to conduct research at MAM Limpung. The authors also express gratitude to the STKIP Muhammadiyah Batang lecturer for the support that has been given so that this research can be completed smoothly.

\section{REFERENCES}

[1] Eriyenti Putri D. Preliminary research of development learning design of system of two linear equations based on realistic mathematics education. J Phys Conf Ser. 2019;1317(1).

[2] As'ari AR, Mahmudi A, Nuerlaelah E. Our prospective mathematic teachers are not critical thinkers yet. J Math Educ. 2017;8(2):145-56.

[3] Vinner S. Mathematics education: Procedures, rituals and man's search for meaning. J Math Behav. 2007;26(1):1-10.

[4] Laurens T, Batlolona FA, Batlolona JR, Leasa M. How does realistic mathematics education (RME) improve students' mathematics cognitive achievement? Eurasia J Math Sci Technol Educ. 2018;14(2):569-78.

[5] Simon MA. An emerging methodology for studying mathematics concept learning and instructional design. J Math Behav. 2018;52(August):113-21.

[6] Setyaningrum VF, Hendikawati P, Nugroho S. Peningkatan Pemahaman Konsep Dan Kerja Sama Siswa Kelas X Melalui Model Discovery Learning. Prisma. 2018;1:810-3.

[7] Nisa S, Rohaeti T, Rustika P. Analisis pemahaman konsep hasil evaluasi belajar peserta didik (sudi Kasus Pada Sub Materi Fungsi Eksponensial). 2020;11(2):51-66.

[8] Amran A. Upaya Meningkatkan Hasil Belajar Peserta Didik Pada Materi Persamaan Eksponensial Melalui Model NHT. J IPA Pembelajaran IPA. 2019;3(1):30-5.

7 | V o 1. 1; I s s u e, 1 
Ordinal: Innovation in Research, Development, and Learning on Mathematics Education Journal

[9] Irfan Taufan Asfar AM, Iqbal Akbar Asfar AM, Darmawati, Darmawan D. The Effect of REACE (Relating, Exploring, Applying, Cooperating and Evaluaring) Learning Model Toward the Understanding of Mathematics Concept. J Phys Conf Ser. 2018;1028(1).

[10] Raj Acharya B. Factors Affecting Difficulties in Learning Mathematics by Mathematics Learners. Int J Elem Educ. 2017;6(2):8.

[11] Subanji. Teori Defragmentasi Struktur Berpikir Dalam Mengkonstruksi Konsep dan Pemecahan Masalah. Malang: UM Press; 2016.

[12] Kadek Adi Wibawa. Defragmenting Struktur Berpikir Pseudo dalam Memecahkan Masalah Matematika. 1st ed. Sleman: Deepublish; 2016.

[13] Dewi FC, Mahani P, Wijayanti D, Islam U, Agung S, Islam U, et al. S Tudents ' Epistemological Obstacles in Exponential Equation Material. 2021;4(2018).

[14] Sa'aduddien Khair M, - S, Muksar M. Kesalahan Konsep dan Prosedur Siswa dalam Menyelesaikan Soal Persamaan Ditinjau dari Gaya Berpikir. J Pendidik Teor Penelit dan Pengemb. 2018;3(5):620-33.

[15] Muslim RI, Usodo B, Pratiwi H. Pseudo Thinking Process in Understanding the Concept of Exponential Equations. IOP Conf Ser Earth Environ Sci. 2021;1808(1).

[16] Armstrong SJ, Peterson ER, Rayner SG. Understanding and defining cognitive style and learning style: A Delphi study in the context of educational psychology. Educ Stud. 2012;38(4):449-55.

[17] Kusumaningsih W, Saputra HA, Aini AN. Cognitive style and gender differences in a conceptual understanding of mathematics students. J Phys Conf Ser. 2019;1280(4).

[18] Setiawan A, Degeng İ, Sa'dijah C, Praherdhiono H. The Effect Of Collaborative Problem Solving Strategies And Cognitive Style On Students' Problem Solving Abilities. J Educ Gift Young Sci. 2020;8(4):1618-30.

[19] Witkin HA, Moore CA, Goodenough D, Cox PW. Field-Dependent and Field-Independent Cognitive Styles and Their Educational Implications. Rev Educ Res. 1977;47(1):1-64.

[20] Mawardi AV, Yanti AW, Arrifadah Y. Analisis Proses Berpikir Siswa dalam Menyelesaikan Soal HOTS Ditinjau dari Gaya Kognitif. J Rev Pembelajaran Mat. 2020;5(1):40-52. 